\title{
28. Ecological aspirations of youth: how higher education could fall between two stools
}

\section{Alessia Lefébure}

Young people believe they have a responsibility to make a better world but do not feel adequately prepared to do so. This is a serious challenge for higher education institutions who want to meet these expectations and keep recruiting - as they often say - the best and the brightest. The ambitions and aspirations of young people are increasingly converging throughout the planet. Surveys and polls have never been as consistent as in 2019. Over the past 18 months, they have been revealing growing concerns for societal issues at large, but most importantly, for the ecological transition, which higher education institutions cannot ignore.

Released in January 2020, an international barometer measured the perceptions of young people about their future and about how prepared and confident they are. Conducted in 20 countries worldwide, the study analyzes the responses of more than 9000 young people aged between 16 and 25. More than 87 percent of the students surveyed believe their generation is responsible for improving the world and 85 percent express worries about the state of the planet. These students clearly say they are worried about the future, climate change and the environment being the major concern for 82 percent of them. Interestingly, climate change has become the second main source of preoccupation, almost as much as poverty and social inequality ( 84 percent). ${ }^{1}$

In the same year, Amnesty International and Ipsos asked 10000 people between the ages of 18 and 25 in 22 countries to choose up to five concerns. Climate change was one of the most important issues facing the world for 41 percent of the respondents, becoming the most commonly cited globally, ahead of pollution ( 36 percent) and terrorism ( 31 percent). ${ }^{2}$

The ecological concern has a direct impact on the expectations of the graduates towards their future employer. More and more young people are wary of employers and corporates that are not actively involved in the common fight for the ecological and economic transition. Another 2019 survey, conducted a few months earlier among a smaller group of young people in 
five European countries (2500 individuals, aged 16-25, in France, Germany, Spain, the United Kingdom and Belgium), reveals a number of unusual criteria when choosing the first job. The level of salary, unsurprisingly, is still the main criterion, ahead of work-life balance, equal career progression and a purpose-driven job. Nevertheless, the corporate social responsibility (CSR) of the employer pops up among the five most cited criteria, counting for 11 percent and 12 percent of the young people's responses. In other words, even if not the majority, a growing share of the young European graduates evaluates - today more than yesterday - the CSR commitment of the company before applying for a job. ${ }^{3}$

Country-based enquiries show similar results. According to the latest Boston Consulting Group (BCG)/Conference des Grandes Écoles (CGE)/Ipsos barometer, released in January $2020,{ }^{4}$ students and graduates of French engineering and management schools express a massive disappointment towards the CSR commitment of large companies. Out of 6200 students and alumni of 187 elite schools in France, 62 percent accuse the corporate world of greenwashing. Even though they acknowledge that companies engage more today than ten years ago in CSR, they still consider such engagements motivated by the need to improve their image, not by conviction. This does not prevent them yet from wanting to join these companies for their career, particularly in the two most wanted areas for their first job: environment (76 percent) and energy (62 percent).

Commenting on these results, Anne-Lucie Wack, the president of the CGE, highlights a change in the relation between the young graduates and their future employers. Today's students intend to give meaning to their professional life and make it widely known. "They will not be hired by a company, they will be hired for a company!" she says. In other words, they want - more than their predecessors did - their aspirations to match the values of the company they join. Instead of making them sweet dreamers, their strong concern for the planet makes them more demanding.

What lessons should we learn from these recent surveys? Each of these figures might not seem striking but the convergence of the aspirations and the trends are noteworthy. A whole cohort of talented and well-trained young professionals starts questioning the values and the commitment of their future employer. Moreover, once in the company, the youngest are determined to contribute to a broader goal. In a global context where one student out of four makes the causes they support their main criteria when choosing a job, ${ }^{5}$ not only are the employers under increasing scrutiny, they should also align position and reputation with the social and ecological aspirations of the newcomers on the job market.

The alignment between the young graduates and their employers is not always easy when it comes to the environment. The younger generations have 
clear professional aspirations and values but do not feel prepared to embrace them in terms of the required skills. In some cases, this feeling of unpreparedness builds on what several psychologists define as "eco-anxiety" or "climate anxiety", a recent mental distress that many adolescents and students develop as they become more aware of the state of the environment. ${ }^{6}$ Future employers would like to offer jobs matching these aspirations and values but cannot always do so, because - they say - the young graduates are not sufficiently prepared either. The mismatch might lie with the higher education system.

Young people traditionally enroll in higher education for three main reasons: to increase their knowledge, to be prepared for the future, and find a job. The 2020 WISE Global Education Barometer ${ }^{7}$ shows that, while young people are globally satisfied with their education ( 80 percent of the responses), they would like to see improvements in the way they learn the twenty-first-century skills that will make them ready to face their future and the global challenges ahead. Only 43 percent of the surveyed students worldwide feel ready to understand big societal issues and take action in finding solutions.

If the new generation is expecting action and commitment from their future employers, they are also questioning the higher education system in its capacity to prepare them for the challenges of the ecological transition. Youth will have to act and work in a complex and demanding world; they feel unprepared to do so and are now asking both the employers and the higher education institutions to take their share of responsibility and liability.

Confronted with fierce competition for students and declining enrolment (e.g., in the US), the world of higher education faces a multiple and often contradicting challenge: meeting the expectations of the future students and maintaining the trust of the job market concerning its capacity to prepare and equip youth with the skills and competencies of tomorrow, while providing the foundations for critical thinking and for effective citizenship. Several large corporates already offer their own in-house training programs and apprenticeships, expressing at the same time the capacity to complement traditional education and perhaps a kind of mistrust with regard to the capacity of the higher education system to teach the actual skills that they will need in order to contribute to solutions.

The well-documented growing concern of the new generations for climate change and the environment starts to have an impact on the marketing and recruitment campaigns of universities, to the point that the United Nations Environment Programme (UNEP) proposes on its website a toolkit called "Greening Universities". ${ }^{8}$ Thanks to this initiative, university managers can find inspiration and resources in order to "develop and implement their own transformative strategies for establishing green, resource-efficient and low carbon campuses". ${ }^{9}$ 
The leaders of universities have clearly understood the magnitude of the task. Many have taken action to send signals to their two constituents - students and employers - in order to retain the former and to prove their relevance to the latter. Thus far, these actions are mainly public declarations, manifestos, op-eds and charts. The president, usually joined by a few members of the faculty, often personally embodies the commitment of the institution.

As an illustration of this kind of institutional commitment, in the aftermath of the Paris COP21, under the leadership of Columbia University Mailman School of Public Health, 115 schools of public health and schools of medicine from all continents decided to launch a common initiative, aiming at educating tomorrow's health and public health professionals on the health impacts of climate change. In 2017, they officially joined a Global Consortium on Climate and Health Education (GCCHE), sharing the same "imperative for quick action on many fronts: to recognize and respond to climate-health threats; prevent climate change at its source by reducing heat-trapping greenhouse gas emissions; support 'greener' systems throughout the economy, including healthcare; understand the health co-benefits of adaptation and mitigation; and communicate effectively about these issues". ${ }^{10}$ The presidents of these health profession schools acknowledge that climate and health as a topic is underrepresented in the curricula. They agree on the need for further development of the knowledge and the skills of all the future professionals in this area throughout the world, so that they can act, prevent, reduce and respond to the health impacts of climate change. The consortium operates as a resource provider, a space for exchange of practices and information, a facilitator for partnerships, an advocate for spreading the commitment out to other schools. In the absence of any outcome report and data, it is difficult to evaluate its real capacity to produce any significant change in terms of course development and increase in the quality and quantity of teaching devoted to the ecological transition in the health professionals' core curriculum.

Similar initiatives have been flourishing in different regions of the world over the past months, suggesting at least a growing awareness among the university leaders. In the UK, for example, the 24 leading universities composing the Russell Group publicly declared in December 2019 their commitment to "tackling climate change through research, teaching and more sustainable practices". In their joint statement, these universities clearly position themselves as major players in the search for solutions to the common energy and climate challenges, thus fully endorsing their responsibility. Following Columbia Mailman's path, the Russell Group universities created an Environmental Sustainability Network in order to "learn from each other, boost efforts to cut waste, increase recycling", and reduce $\mathrm{CO}_{2}$ emissions on campus. Their declaration speaks directly to students and openly addresses the questions of the aspirations of the future generations: "Though we do not yet have all the 
answers, we are striving to empower existing and future generations with the knowledge and confidence to protect our planet, as we each work towards reducing our own impact on the world around us". Each of the statement's words seems to be a direct answer to the questioning that all the barometers are highlighting: "As educators responsible...we aspire to give every student the opportunity to become environmentally literate... We provide all our undergraduates and postgraduates with the opportunity to build environmental sustainability into their wider student experience". ${ }^{11}$ Surprisingly enough, the declaration does not push the ambition further, as it does not mention the need to build environmental sustainability into students' future professional life. Nevertheless, throughout the statement, the message of these universities to the various stakeholders is clear, and it is about the commitment to take action, to contribute to the transition through research, education and through an ecological behavior.

In France too, higher education leaders are becoming vocal about their determination to introduce more teaching related to climate and environment. In September 2019, the press released declarations signed by presidents of universities and elite schools of the country, joined by thousands of faculty members, scholars and ordinary citizens..$^{12}$ They call to be able to train all higher education students in climate and ecological issues and they ask the government to devote additional financial resources to this goal. The vast majority of presidents and deans of French higher education institutions including the deans of several civil service schools, in charge of the training of the French high civil servants - seem to be willing to "position the climate as the primary emergency" and to engage their communities in a massive, rapid and efficient transformation. They mention three levels of action: support the students with the necessary encouragements, knowledge and skills so that they can be massively involved in ecological, economic and societal transformations; train all the staff; and introduce responsible practices into the operation of the campus and student life. ${ }^{13}$

As in the previous initiatives, it is hard to evaluate the effectiveness of these claims and their capacity to produce concrete changes in the curriculum and in the teaching practice of the French higher education institutions. Yet, the introduction of climate- and energy-related courses in the fundamental core curriculum of all the students, no matter the field of specialization, is a crucial issue. Indeed, the current top management and leadership - private and public sector alike - is not sufficiently aware of the nature and the extent of the climate and energy challenges to take the right decisions. Responding to the climate challenge requires new training for all managers and public officials, and the introduction of climate and ecological concern in all public policies and corporate strategies. ${ }^{14}$ 
Actually, in spite of the massive engagement of their presidents, higher education institutions are slow in responding to the needs of the ecological transition, often decoupling their narrative and their practice. Given the complexity of the nature of the challenges, the amplitude of the shift, the degree of uncertainty and the planetary scale of interconnection, universities must undertake a profound rethinking of the current curricula and teaching methods. Preparing the future generation to understand the situation, to evaluate the impact of their decision, to act in a timely way, and to find solutions, is an ambitious goal. Universities and schools are unprepared for this difficult task and their traditional research organization, based on departments and disciplines, is obsolete and ineffective in the new context.

A 2019 survey conducted by the International Association of Universities (IAU) gives a state-of-the-art overview of the current engagement of the higher education community around the world on the Sustainable Development Goals (SDGs). In comparison with the results of the first survey of 2016, the universities' commitment is growing and often leads to including sustainable development in their strategic plans. More than half of them declare they allocate a specific budget to sustainable initiatives and projects. Nonetheless, the survey points out a number of difficulties that prevent deeper transformation and the incorporation of sustainable development into every activity: the lack of funding, the lack of staff, and the lack of training opportunities. If the majority of universities (65 percent) offer a growing number of sustainability-focused courses, these courses are usually specialized - belonging to STEM (science, technology, engineering, and mathematics) - and not widely known on campus. Trans- and inter-disciplinary approaches are rare and holistic perspectives seem challenging to implement. Several respondents explicitly mentioned "the lack of reward or gratification mechanisms for transdisciplinary courses" among the difficulties. ${ }^{15}$

In France, the situation is no better than elsewhere. As three students of the École Polytechnique point out, their school, like many others, "mainly trains specialists who know nothing about sustainable development, or environmental specialists who know nothing of other sectors. These typical profiles are not up to the challenge. And those who have chosen the right optional courses are far too few". ${ }^{16}$ At the country level, only very few teaching programs (11 percent) offer mandatory courses related to the energy and climate challenges, according to a report published in March 2019 on higher education and climate. ${ }^{17}$ Based on an extensive analysis of a sample of 34 higher education institutions in France and 140 interviews, the authors' findings reveal three kinds of inequalities in terms of access to a thorough education on climate issues. Engineering schools offer more courses than business schools and, even in universities, students enrolled in engineering and STEM programs have more climate-related courses than those in other fields. Finally, these 
courses are usually offered at the graduate and postgraduate level, almost never at the undergraduate level.

The multidisciplinary dimension of the ecological transition - mobilizing knowledge from geography to biology, from philosophy to economics through earth sciences - adds an extra obstacle to the necessary adaptation of higher education and generates various forms of resistance at all levels. As the French intellectual Edgar Morin would say, "Our cognitive structure which, within our civilization, separates the human (individual and society) from the natural biological and physical, is a major hurdle for ecological awareness". ${ }^{18}$ Indeed, a core curriculum course, common to all teaching programs and across disciplines, is much more difficult to achieve than any specialized teaching program within the department of earth and environmental sciences. Yet, what is expected from higher education institutions is the capacity and the promise to train all students and all future professionals, not only those who will work in the energy and environment field, to be able to navigate the complexity. Only a strong demand from future students will accelerate these curricula changes, as long as these students are consistent to their values once in the job and know how to respond to the contradictions they will face in their professional life.

\section{NOTES}

1. Ipsos (2020), "The WISE Global Education Barometer 2020: youth perceptions on their education and their future", 30 January, accessed 26 August 2020 at https:// www.ipsos.com/en/wise-global-education-barometer-2020.

2. Amnesty International (2019), "Climate change ranks highest as vital issue of our time - Generation Z survey”, 10 December, accessed 26 August 2020 at https:// www.amnesty.org/en/latest/news/2019/12/climate-change-ranks-highest-as-vital -issue-of-our-time/.

3. WISE, Ipsos and JobTeaser (2019), "Preparing the new generation for the future of work: a survey of European youth, employers and education actors", February, accessed 26 August 2020 at https:/www.ipsos.com/sites/default/files/ct/news/ documents/2019-02/wiseparis_etude_en_web_v2.pdf.

4. BCG, CGE and Ipsos (2020), Baromètre "Talents: ce qu'ils attendent de leur employ”, accessed 26 August 2020 at https://image-src.bcg.com/Images/Etude -BCG-CGE-IPSOS_tcm9-237878.pdf.

5. WISE, Ipsos and JobTeaser (2019), in note 3.

6. Anna Kelly (2017), "Eco-anxiety at university: student experiences and academic perspectives on cultivating healthy emotional responses to the climate crisis", Independent Study Project (ISP) Collection, No. 2642, accessed 26 August 2020 at https://digitalcollections.sit.edu/isp_collection/2642.

7. WISE (2020), "WISE Global Education Barometer - youth perceptions on their education and their future", accessed 26 August 2020 at https://www.wise-qatar .org/wise-global-education-barometer-2020/.

8. UNEP (2013), Greening Universities Toolkit: Transforming Universities into Green and Sustainable Campuses: A Toolkit for Implementers, accessed 26 August 
2020 at https://www.unenvironment.org/resources/report/greening-universities -toolkit-transforming-universities-green-and-sustainable.

9. Ibid.

10. The Earth Institute, Columbia University (2017-18), "Global Consortium on Climate and Health Education", Earth Institute Research Projects, accessed 26 August 2020 at https://www.earth.columbia.edu/projects/view/863.

11. Russell Group (2019), "Joint statement on environmental sustainability", 9 December, accessed 26 August 2020 at https://russellgroup.ac.uk/news/russell -group-publishes-joint-statement-on-environmental-sustainability/.

12. Le Journal du Dimanche (2019), "Formons tous les étudiants aux enjeux climatiques': l'appel de 80 dirigeants d'établissements", 14 September, accessed 26 August 2020 at https://www.lejdd.fr/Societe/exclusif-formons-tous-les-etudiants -aux-enjeux-climatiques-lappel-de-80-dirigeants-detablissements-3919612.

13. Le Monde (2019), "Les universités et grandes écoles doivent intégrer l'urgence climatique dans leur stratégie", 19 September, accessed 26 August 2020 at http:// www.cpu.fr/actualite/les-universites-et-grandes-ecoles-doivent-integrer-lurgence -climatique-dans-leur-strategie/.

14. Le Monde (2019), "Répondre au défi climatique nécessite de former l'ensemble des agents publics", 4 December, accessed 26 August 2020 at https:// www.lemonde.fr/idees/article/2019/12/03/repondre-au-defi-climatique-necessite -de-former-1-ensemble-des-agents-publics_6021502_3232.html?utm_medium= Social\&utm_source $=$ Twitter\#Echobox $=15 \overline{75} 402722$.

15. Stefanie Mallow, Isabel Toman and Hilligje van't Land (2020), Higher Education and the 2030 Agenda: Moving into the "Decade of Action and Delivery for the SDGs": IAU 2nd Global Survey Report on Higher Education and Research for Sustainable Development, accessed 26 August 2020 at https://www.iau-aiu.net/ IMG/pdf/iau_hesd_survey_report_final_jan2020.pdf.

16. La Jaune \& La Rouge (2020), "Les élèves de l'école interpellent le système", Magazine, No. 751, January, accessed 26 August 2020 at https://www .lajauneetlarouge.com/les-eleves-de-lecole-interpellent-le-systeme/.

17. The Shift Project (2019), Mobiliser l'Enseignement Supérieur pour le Climat, March, accessed 26 August 2020 at https://theshiftproject.org/wp-content/uploads/ 2019/04/Rapport_ClimatSup_TheShiftProject-2019.pdf.

18. Edgar Morin (2020), "En finir avec les malheurs de l'écologie", Libération, 2 February, accessed 26 August 2020 at https://www.liberation.fr/debats/2020/02/ 02/en-finir-avec-les-malheurs-de-1-ecologie_1776814. 